\title{
Accounting for Leases and the Failure of Convergence
}

\author{
By Roger Hussey ${ }^{*}$
}

The Financial Accounting Standards Board (FASB) in the U.S. and the International Financial Reporting Standards(IASB) commenced a work programme towards convergence and the leasing project was added to their agenda in July 2006. The aim of the project was to develop a single approach to lease accounting that would ensure that all assets and liabilities arising under lease contracts would be recognised in the statement of financial position. In March 2009, the IASB, jointly with the FASB, published a Discussion Paper Leases: Preliminary Views. The discussion paper was open for comment until 17 July 2009. In August 2010, the IASB, jointly with the FASB, published an Exposure Draft Leases. The Exposure Draft was open for comment until 15 December 2010. The responses were not favourable. In 2013, a second Exposure Draft ED/2013/6 was issued. Our analysis of the Comment Letters submitted show that the majority of respondents disagreed with many of the proposals in the Discussion Paper. Based on these results the research strategy was amended to conduct a content analysis of the Comment Letters submitted in response to Exposure Draft 2. The analysis concentrated on UK and US companies but included all their Comment Letters, a total of 137. The results demonstrate, at least for companies, that the US respondents overwhelmingly rejected either the accounting concept or the standard. A further analysis revealed that the greatest disagreement was with the concept of a lease being recognised as an asset in the financial statements.

\section{Introduction}

Leasing transactions are significant in business activities and for many years accounting regulations have required leases be classified as either an operating lease or a finance (capital lease). An operating lease is treated as a rental expense on the Income Statement. A finance lease is treated as an acquisition of an asset and both the asset and liability appear on the balance sheet.

Considerable concern has been expressed in respect of accounting by lessees. There is evidence that suggests some companies will classify leases as operating with the sole intention of avoiding showing the asset and liability on their balance sheet. This can enhance the perceived financial position of the company and users of financial statements do not obtain the complete information.

The requirements for identifying whether a contract is for a finance lease or an operating lease has not been identical in the U.S. and internationally. The U.S. has had what is known as bright line rules to define the two types of

${ }^{*}$ Emeritus Professor at the University of the West of England and the University of Windsor Canada, Odette School of Business, University of Windsor, Canada. 
leases. The categorising of leases is established by very precise amounts. The standard (SFAS 13) defines a capital lease as one under which any one of the following four conditions is met:

1. the present value at the beginning of the lease term of the payments not representing executory costs paid by the lessor equals or exceeds $90 \%$ of the fair value of the leased asset;

2. the lease transfers ownership of the asset to the lessee by the end of the lease term;

3. the lease contains a bargain purchase price;

4. the lease is equal to $75 \%$ or more of the estimated economic life of the leased asset

One could argue that it does not require much ingenuity to draw up a contract where the percentages fall on the most advantageous side for the company and the information it wishes to disclose.

The international standard (IAS 17- Accounting for Leases) has been principles-based. It avoids setting out quantitative thresholds, as is the case in the U.S. standard, but states that the classification of a lease depends on the substance of the transaction rather than the form. The standard describes situations that would normally lead to a lease being classified as a finance lease, including the following:

- the lease transfers ownership of the asset to the lessee by the end of the lease term;

- the lessee has the option to purchase the asset at a price which is expected to be sufficiently lower than fair value at the date the option becomes exercisable that, at the inception of the lease, it is reasonably certain that the option will be exercised;

- the lease term is for the major part of the economic life of the asset, even if title is not transferred;

- at the inception of the lease, the present value of the minimum lease payments amounts to at least substantially all of the fair value of the leased asset; and

- the lease assets are of a specialised nature such that only the lessee can use them without major modifications being made. An example where certain equipment is required for certain manufacturing operations unique to the organization

The standard also provides additional examples that could lead to the agreement being classified as a finance lease:

- If the lessee is entitled to cancel the lease, the lessor's losses associated with the cancellation are borne by the lessee;

- gains or losses from fluctuations in the fair value of the residual fall to the lessee (for example, by means of a rebate of lease payments); and 
- the lessee has the ability to continue to lease for a secondary period at a rent that is substantially lower than market rent

Considerable concern has been expressed in respect of accounting by lessees. There is evidence that suggests some companies will classify leases as operating with the sole intention of avoiding showing the asset and liability on their balance sheet. This can enhance the perceived financial position of the company and users of financial statements do not obtain the complete information.

To prevent these abuses there have been several demands that accounting standards are amended. Agreeing on the proper accounting treatment for these transactions has been difficult. In 1996, the G4+1 published a special report entitled Accounting for leases: A new approach. The report advocated an approach to lease accounting, whereby the distinction between finance leases and operating leases would be removed. Lessees would recognize as assets and liabilities all material rights and obligations arising under lease contracts. (McGregor 1996).

There was no changes made to existing accounting regulations in any country, but the topic was to become a major issue when the drive for all countries to use agreed international accounting standards reached a critical stage.

Given the substantial differences between the U.S. and International Standards (IFRSs) and the claimed abuse of the U.S. standard, it is not surprising that a leasing project was added to the International Accounting Standards Body's agenda in 2006 to develop a new international accounting standard that addresses the deficiencies in existing regulations for accounting for leases. The US Financial Accounting Standards Board's involvement stems from its commitment originally given in the Norwalk agreement, to converge U.S. standards with International standards. The aim of the project is to develop a new single approach to lease accounting that would ensure that all assets and liabilities arising under lease contracts are recognised in the statement of financial position.

In March 2009, the IASB, jointly with the FASB, published a discussion paper Leases: Preliminary Views. The discussion paper was open for comment until 17 July 2009. In August 2010 the IASB, jointly with the FASB, published an exposure draft Leases. The exposure draft was open for comment until 15 December 2010. The responses were not favourable and in January 2011, a Comment letter summary on ED 2010 was issued to be followed by a second Exposure Draft ED/2013/6.

The motivation for this current research was to identify the nature and source of the respondents' criticisms of the original Discussion Paper that led to the unusual step of a second Exposure Draft. A Contents Analysis was therefore conducted of the first 150 responses to the Discussion Paper. On the publication of the second Exposure Draft, a further content analysis was conducted of all submissions by UK and US companies. 
The next section of this paper is a review of the literature and this is followed by an explanation of the methodology adopted. The main part of the paper provides the analysis and discusses of the findings. This is followed by an explanation of the limitations of the research and suggestions for future research.

\section{Literature Review}

It is argued that in most countries, under national standards, companies can structure agreements to avoid the quantitative thresholds and define the lease which best meets their purposes (McBarnet and Whelan 1992). In 1996, the G4+1 published a special report entitled Accounting for leases: A new approach. The report advocated a conceptual approach to lease accounting, whereby the distinction between finance leases and operating leases is removed. Lessees would recognize as assets and liabilities all material rights and obligations arising under lease contracts. (McGregor 1996).

Many studies have claimed that companies categorise leases as operating as a form of off-balance sheet finance. This has an impact on lessees' financial statements and financial ratios that is avoided if they were required to capitalise all leases (Ashton 1985, Imhoff et al. 1991, 1993, Bennet and Bradbury 2003). The findings appear to be consistent in several countries and indicate that leverage ratios would be significantly increased by capitalising leases, other performance ratios would be also affected but not so significantly and certain industries such as airlines, retailers, hotels, and vehicle distributors would be most impacted.

In a Canadian study, the above findings were confirmed (Durocher 2008). The results indicate that capitalizing operating leases would lead to the recognition of important additional assets and liabilities on the balance sheet. It would therefore significantly increase the debt-to-asset ratio and significantly decrease the current ratio. These results were noted across all industry segments in the sample. Income statement effects were generally less material. Significant impacts on return on assets, return on equity, and/or earnings per share were noted in only three industry segments: merchandising and lodging, oil and gas, and financial services.

One can argue that the findings of the above studies are not surprising. If you incorporate items on the balance sheet that were previously omitted you will obtain different accounting ratios. This result, in itself, does not provide justification for including items on the balance sheet. However, if there is evidence that users require the information and, on a conceptual basis, it can be incorporated, there appears to be no barriers for doing so.

There have been several studies that demonstrate how lease information is perceived and interpreted by the preparers and users of financial statements. The earliest studies tended to concentrate on users' understanding of the different impact of finance and operating leases. For example, Breton and Taffler (1995) conducted a study with 63 UK stockbroker analysts in which not one of the 
analysts adjusted amounts or ratios for operating leases. Gopalakrishnan and Parkash (1996) surveyed CFOs of all Fortune 500 firms (borrowers), 400 chief credit officers of banks (lenders), and to private placement department heads of 100 insurance firms (lenders). Lenders believed all items (e.g., capital leases, deferred tax liabilities, pension obligations, operating leases, etc.) to be more like liabilities than did borrowers.

A UK study further analyses the distinct views of preparers and users. Beattie, Goodacre and Thomson, (2006) surveyed 415 finance directors of UK firms that were included in the UK quoted industrials (preparers), 400 financial analysts from a London-based associate members list (users), and 72 fund managers listed in CA Magazine (users). Respondents were asked to indicate the extent to which they agreed with a number of statements regarding lease information.

Some of the main findings of the study were that both users and preparers considered that companies abused the standard to achieve off-balance sheet finance and that the present information is of little value to users. Users were more likely than preparers to request all leases to appear on the balance sheet and preparers were more likely to consider that the costs of any changes would outweigh the benefits. The response rates to this study were not high and the strength of the finding open to various interpretations.

A Canadian study by Durocher and Fortin (2009) investigated private business bankers' preferences on the issue of capitalizing all non-cancellable lease contracts, including operating leases, as suggested by the G4+1. The study found that while bankers use both capital and operating lease information, they give significantly more consideration to the former when analysing private business loan requests. Accordingly, operating lease information receives less attention than capital lease information in the credit-granting decision process. The authors conclude that "the capitalization of operating leases would improve bankers' ability to evaluate long-term finance commitments of lessees and, as a result, bankers would increase their estimates of the risks involved in providing finance to them" (Durocher and Fortin 2009: 39).

Criticisms on the ethicality of intentionally structuring lease contracts to avoid disclosing leased asset and liability amounts are voiced frequently and Frecka (2008) contends that the "slippery slope" of rule-based accounting for synthetic leases and special purpose entities, led to the accounting debacles at Enron and other companies. Research has shown that companies complying with a US standard that contains bright linerules are more likely to classify leases as operating than companies that use IFRS and aprinciple based standard (Collins et al. 2012).

Given this background, it is not surprising that in their initial discussions on convergence the IASB and FASB agreed to look at a potential lease accounting project. On 19 July 2006 both bodies added this topic to their agendas and at a joint meeting in April 2008 staff was instructed to develop a technical plan that would result in a new leasing standard by mid-2011 at the latest. 
In the first Discussion Paper (IASB, 2009), the IASB and FASB reached the tentative decision that in a simple lease the lessee obtains the right to use the leased item and that meets the definition of an asset. The related obligations to pay rentals meet the definition of a liability. It is proposed that there will be a new accounting model where the lessee recognises the "right to use" an asset and a liability on the balance sheet. There will be no operating leases. The Discussion Paper also made proposals on various components of a lease contract and methods of measurement.

At a subsequent meeting (IASB 2010) the boards tentatively reconfirmed the right-of-use approach for lessees. That approach, as described in the Discussion Paper Leases: Preliminary Views proposes that a lessee should recognise for all leases:

- an asset representing its right to use the leased item for the lease term (the right-of-use asset)

- aliability for its obligation to pay rentals.

\section{Methodology}

Beattie et al. (2006) have made the point that most surveys of attitudes to standards have involved the preparers of financial statements and not the users, in particular where it is a question of regulatory reform. Standards are developed in a framework where companies, auditors and other associations have well organised lobbying strengths and use them (Georgiou 2004) and that the absolute difference between the overall level of preparers and users lobbying could be huge. (Beattie et al. 2006).

Given the difficulties in identifying a sample of users and the problems of a worthwhile response rate being achieved, it was decided to conduct a content analysis of the responses to the Discussion Paper issued by the FASB and IASB and the final Exposure Draft 2. When the Boards issue a Discussion paper or Exposure Draft, comments are invited and these are posted on the website of the two bodies. Access to this gave a substantial range of opinions.

In content analyst is, a document is normally scrutinised, although the technique can be used to analyse other forms of communication, such as newspapers, broadcasts, audio recordings of interviews, and video recordings of non-participant observations and focus groups. Mostyn (1985) claims the technique was used to analyse communications as early as 1740 . The aim of the method is to identify emerging characteristics, themes, patterns or biases (Leedy and Ormrod 2005).

There are two main approaches to content analysis: mechanistic and interpretive (Hooks and vanStadden 2011). For this study, a mechanistic method was adopted and the analysis is based on volumetric or frequency capture rather than an interpretative method. In other words, the exact word such as "definition" or "measurement". 
For the coding units, themes were identified. This was aided as the letters were responding to specific points raised in the Discuss Papers so boundaries were established on the topics to be addressed. The main themes selected for our analysis are shown on the following table with a brief example from the Comment Letters.

Theme

The requirements are too complex CL 29

Useful information not generated CL103

The measurement method is deficient

Concern over definition of a lease CL 2

\section{Example}

Major concern with the right of use model proposed in the Discussion Paper is that it will create excessive complexity and burdens for preparers. We do not perceive value in recognising a right of use asset and obligation in the balance sheet

What is not firmly measurable should not be recognised CL 130

I am concerned that you good folk have lost touch with reality, as evidenced by your latest proposal to treat every lease as both an asset and a liability

\section{Findings}

\section{Discussion Paper}

In March 2009 the IASB and the IASB, published a Discussion Paper Leases: Preliminary Views. The discussion paper was open for comment until 17 July 2009. A summary of the responses was prepared by the technical staff of the FASB and the IASB for discussions at public meetings. The IASB meeting was held on Sept 152009 and the FASB on 16 Sept.2009.

According to the staff's summery approximately half of the respondents supported the overall principles and objectives set out in the discussion paper. Approximately one-third of the respondents did not support the boards' preliminary views.

Those supproting the principles of the discussion paper recognised the problems with existing lease accounting standards. They accepted that the distinction between between operating and capital (finance) leases was arbitrary, artificial, and created accounting complexity. The right-of-use model would account better for lease transactions. Doubts were expressed over the complexity of the model.

Preparers and industry organisations formed the majority of those not supporting the new model for accounting for leases. They aregued that: 
- that the right-of-use model is not applicable to all leases because lease arrangements are very diverse and their economic substance can range from a rental of an asset to a financed purchase.

- the existing lease accounting model properly reflects these economic differences by distinguishing between operating and capital (finance) leases.

- that the proposed model is too complex and that its benefits would not outweigh its costs.

Unfortunately, the summary did not give specific numbers so it is somewhat difficult to determine the strength of the support for the proposals in the Discussion Paper. We therefore decided to conduct a content analysis based on the comment letters to the Discussion Paper.

A total of 302 comment letters were received in response to the Discussion Paper. Standard letters that were from members of any Associations were excluded but the main letter from the Association itself was retained. Responses from EU and US companies were identified and this gave a total of 214 comment letters for analysis.

Hypothesis 1. Respondents from the US are more likely to disagree with the standard than those from the UK.

The basis of this hypothesis was that UK organizations had changed to international accounting standards fin 2005 and therefore a change in a standard was likely to be less controversial. Also, US respondents had been familiar with their own rules-based standard and were less likely to accept the porposals in the Exposure Draft that were principles based.

In the following analysis, the responses in the Comment Letters from the EU are compared to those from the US for each of the main themes. First, we consider the doubts raised on the definition of a lease. The results are shown in table 1.

Table 1. Concern over the definition of a lease

\begin{tabular}{|l|c|c|c|c|c|c|}
\hline & \multicolumn{2}{|c|}{ EU } & \multicolumn{2}{c|}{ US } & \multicolumn{2}{c|}{ Total } \\
\hline & No & \% & No & \% & N0 & \% \\
\hline No & 89 & 67.4 & 33 & 40.2 & 122 & 57 \\
\hline Yes & 43 & 32.6 & 49 & 59.8 & 92 & 43 \\
\hline & 132 & 100 & 82 & 100 & 214 & 100 \\
\hline
\end{tabular}

The majority of the EU respondents (32.6\%) did not express doubts over the definition of a lease whereas the position was reversed for the US respondents (59.8). Further research would be required to identify the reasons and whether both groups were voicing the same doubts or we are considering two different perspectives.

There was unease expressed by the respondents on the definition of an operating lease as a right to use asset. Several of the respondents argued that it 
would have been best to define an asset in the Conceptual Framework project before raising a new definition within the body of a proposed standard. Lengthy discussion was also given to whether such an asset was a tangible asset or an intangible asset. The following Comment Letter 15 captures some of the argument.

We question the proposed model to recognize assets and liabilities for any leases entered into without consideration of whether substantial risks and rewards are transferred. We believe that only such lease contracts that are in substance represent financial transactions for lessees to acquire effective ownership of an asset should be recognized in the statement of financial position

Another view that appears to speak in opposition to the entire purpose of the project is Comment Letter 9

Under the current lease accounting standards, operating leases are accounted for as a rental expense and do not impact small business lessees' liability on financial statements. Because the DP would reclassify operating leases as capital leases, this would substantially increase the debt shown on small business lessees' financial statements. This would also cause these small companies to have financial statements that show reduced earnings and reduced capital. Further, with more assets on their balance sheets, certain small business lessees, like community banks, might be required to increase their capital reserves as risk mitigation to satisfy capital adequacy rules.

There were lengthy comments on the measurement proposals given in the discussion paper.

Although the majority in both groups did not express concerns, the following table demonstrates that those in the US were far more likely to do so.

Whereas the position was reversed for the US respondents (59.8). Further research would be required to identify the reasons and whether both groups were voicing the same doubts or we are considering two different perspectives.

There was unease expressed by the respondents on the definition of an operating lease as a right to use asset. Several of the respondents argued that it would have been best to define an asset in the Conceptual Framework project before raising a new definition within the body of a proposed standard. Lengthy discussion was also given to whether such an asset was a tangible asset or anintangible asset. The following Comment Letter 15 captures some of the argument.

We question the proposed model to recognize assets and liabilities for any leases entered into without consideration of whether substantial risks and rewards are transferred. We believe that only such lease contracts that are in substance represent financial transactions for lessees to acquire effective 
ownership of an asset should be recognized in the statement of financial position

Another view that appears to speak in opposition to the entire purpose of the project is Comment Letter 9

Under the current lease accounting standards, operating leases are accounted for as a rental expense and do not impact small business lessees' liability on financial statements. Because the DP would reclassify operating leases as capital leases, this would substantially increase the debt shown on small business lessees' financial statements. This would also cause these small companies to have financial statements that show reduced earnings and reduced capital. Further, with more assets on their balance sheets, certain small business lessees, like community banks, might be required to increase their capital reserves as risk mitigation to satisfy capital adequacy rules.

There were lengthy comments on the measurement proposals given in the discussion paper. Although the majority in both groups did not express concerns, the following table demonstrates that those in the US were far more likely to do so.

Table 2. The Measurement Guidance is deficient

\begin{tabular}{|l|c|c|c|c|c|c|}
\hline & \multicolumn{2}{|c|}{ EU } & \multicolumn{2}{c|}{ US } & \multicolumn{2}{c|}{ Total } \\
\hline & No. & $\%$ & No & $\%$ & NO & $\%$ \\
\hline No & 87 & 65.9 & 44 & 53.7 & 131 & 61.2 \\
\hline Yes & 45 & 34.1 & 38 & 46.3 & 83 & 38.8 \\
\hline & 132 & 100 & 82 & 100 & 214 & 100 \\
\hline
\end{tabular}

The method of measuring the proposed asset received some criticism. This is particularly so with US companies where $46.3 \%$ considered the measurement guidance deficient compared to $34.1 \%$ of the EU companies.

Some respondents argued that the requirements were too complex and others that they were conceptually impaired. Several of the respondents criticised the method stated in the DP and presented their own solution as demonstrated in CL 282

The initial measurement of the lessee's obligation to pay rentals should be done at weighted average borrowing cost of the enterprise during the period (general borrowing rate).

Normally, the general borrowing rate would be the representative of incremental borrowing rate of the enterprise. and would obviate the need of separate computation for incremental borrowing rate.

Ascertaining incremental borrowing rate is difficult in practice and rate is determined by negotiations and cannot be predicted unless the deal is done. Alternatively, the actual incremental borrowing rate for the period in which the lease transaction is entered can be prescribed. This will 
obviate the need for any guess work and will be realistic based on the borrowings made in the normal course of the business during that period.

Undoubtedly, the methods for measurement proposed are difficult but, as the next table demonstrates complexity, although significant, was only considered an issue by the minority of respondents in both groups.

Table 3. Requirements are too Complex

\begin{tabular}{|l|c|c|c|c|c|c|}
\hline & \multicolumn{2}{|c|}{ EU } & \multicolumn{2}{c|}{ US } & \multicolumn{2}{c|}{ Total } \\
\hline & No & $\%$ & No & $\%$ & N0 & $\%$ \\
\hline No & 94 & 71.2 & 54 & 65.9 & 148 & 69.2 \\
\hline Yes & 38 & 28.8 & 28 & 34.1 & 66 & 30.8 \\
\hline & 132 & 100 & 82 & 100 & 214 & 100 \\
\hline
\end{tabular}

The theme of the complexity of the requirements was a general statement on the entire document and did not always refer to any one particular section such as the measurement guidance. Although the majority in both groups decided that the regulations are not too complex, a higher proportion of the total in the US $34.1 \%$ consider that they are compared to $28.8 \%$ of EU companies.

One trend of the convergence project has been the issue of standards that are more principles based than rules based. This raises the speculation that the US respondents found the absence of the customary "bright line rules' added to the complexity. This is only a hypothesis and it requires elaboration and further research but the absence of clear rules may well raise uncertainties in the minds of some users.

A main thrust of the Discussion Paper was to improve the information given to users. Table 4 demonstrates that $73.3 \%$ of all respondents believed that useful information would not be generated. Table 4 provides an analysis of the two groups.

Table 4. Useful Information would be generated

\begin{tabular}{|l|c|c|c|c|c|c|}
\hline & \multicolumn{2}{|c|}{ Eu } & \multicolumn{2}{c|}{ US } & \multicolumn{2}{c|}{ Total } \\
\hline & No & $\%$ & No & $\%$ & No & $\%$ \\
\hline No & 108 & 81.8 & 49 & 59.8 & 157 & 73.3 \\
\hline Yes & 24 & 18.2 & 33 & 40.2 & 57 & 26.7 \\
\hline & 132 & 100 & 82 & 100 & 214 & 100 \\
\hline
\end{tabular}

Interestingly, it is the majority of respondents in the EU group that believes useful information will not be generated. One could suppose that there is a belief that the IASB's principles based approach captures the nature of transactions and the relevant information is generated.

Given the criticisms of practices by some US companies in side stepping the rules this may explain their slightly greater opinion (40.2\%) on the value of the information that would be disclosed. Some unease was expressed on the ability or willingness of recipients of financial information on leases to make use of the information. This theme of complexity was sometimes paired with 
thetheme of useful information will not be generated, although the latter was frequently quotedwithout reference to complexity.

\section{Exposure Draft 1}

In August 2010 the FASB, jointly with the IASB, published an Exposure Draft Leases. The Exposure Draft was open for comment until 15 December 2010. The staff prepared a paper for a joint IASB/FASB meeting on January 2011. There had been an extensive and premably expensive outrearch with the project and it is worth stating these to demonstrate the commitment that has gone into bringing a change in accounting standards. The outreach activities included

(a)Seven roundtables in London, Hong Kong, Chicago and Norwalk held in December 2010 and January 2011. These were attended by representatives from over 80 interested parties and included one roundtable focused on private and not for profit entities;

(b)Fifteen preparer workshops in London, Tokyo, Seoul, Melbourne, São Paulo, Toronto and Norwalk held in November and December 2010 and attended by representatives from over 90 organisations;

(c) Outreach meetings in which the staff and boards met globally with over 1500 organisations in over 200 meetings since publication of the ED.

The Paper presented by staff, understandably, concentrated on the issues rather than a detailed analysis of responses. This leads to some difficulty in assessing the strength of opinions and whether different groups e.g. prepares and users hold differing opinions.

However, the technical staff concluded that there was general support for the boards' efforts to address criticisms of the current 'bright-lines' approach and to seek to improve information provided to users of the financial statements Most respondents supported the recognition of lease obligations and related assets on the lessee's statement of financial position.

Nevertheless, the following concerns were expressed on the:

- complexity and cost of implementing the proposals, specifically the initial and subsequent measurement of lease assets and liabilities;

- reduced comparability arising from the level of estimation and judgement required by the proposals (eg determination of lease term and calculation of variable lease payments);

- definition of a lease, and whether all arrangements meeting the proposed definition should be accounted for in accordance with the proposals; and

- direction and objectives of the proposals on lessor accounting. 
The Boards began redeliberations on the Leases exposure draft in January 2011. In May 2013, the FASB issued a Proposed Accounting Standards Update (Revised) on Leases (Topic 842) as a revision to the 2010 proposed FASB Accounting Standards Update, Leases (Topic 840).

In the model proposed, most leases would be recorded on the lessee's balance sheet as a right-to-use asset. There would also be a liability recorded as the obligation to make lease payments. However, short-term leases (i.e. leases with a maximum possible term of 12 months or less, including renewal options) can remain off the balance sheet, with lessees/lessors recording lease expense/income on a straight-line basis over the lease term.

There have been criticisms of the proposals and it is argued that:

"the boards should expect to receive numerous comment letters raising valid issues that will require further work. If ED2 is adopted as is, the new rules will provide less useful decision making information than the current rules for both lessee and lessor accounting; however, a few key changes would make the proposed rules both workable and an improvement over current GAAP"'.

Silliman 2012

Using archival data, we find that IFRS-regime firms exhibit a relatively greater tendency to report leases as capital leases, compared to U.S. GAAP firms.

\section{Exposure Draft 2}

In August 2010, the FASB, jointly with the IASB, published an Exposure Draft Leases. The Exposure Draft was open for comment until 15 December 2010.

In August 2013 the FASB, jointly with the IASB, published a second Exposure Draft Leases. Given our experiences with the first stage of the research and the changes that had been made in the Exposure Draft we decided to amend our research strategy.

We continued to concentrate on UK and US companies and firms of accountants, but selected the responses from all comment letters. This avoided the possibility of late responders demonstrating a different opinion to that of early responders. IT also ensured a reasonable sample size.

Generally, US Comment Letters tended to be more forthright in stating their opinion. A UK respondent started their second paragraph as follows:

We welcome the opportunity to comment on the ED, and appreciate that the Board has addressed many of the comments on the 2010 ED. We appreciate the technical challenges that the lease project has produced 
and would expect to see a final standard that is technically sound, practical and has the wide support of both preparers and users.

CL 140

After a few more sentences extolling the benefits of principle of convergence with the US, the second paragraph ends

,,,we believe that the compromises inherent in these proposals do not lead to an improvement in lease accounting, and so we do not support this ED.

The resdpondent accepts the conceptual proposition but disagrees with the proposed standard. The reasons for this disagreement were detailed in 8 pages accompanying the letter.

\section{Coding}

1. Level of agreement

$1=$ disagree with concept of standard i.e. making everything capital leases

$2=$ agrees with concept but disagrees with standard

3 = agrees with standard but expresses major reservations with some points

$4=$ agrees with standard completely or with minor reservations

\section{Possible research questions}

1. US respondents in total are more likely to reject proposals than UK respondents as literature suggests that they prefer the option and ability to capitalise leases as operating leases thus keeping them off the balance sheet

2. There will be no differences in the responses from Accounting firms and accounting bodies in the US and UK because they have been involved with the standard setting

3. US companies a are more likely to reject proposals than UK respondents as literature suggests that they prefer the option and ability to capitalise leases as operating leases thus keeping them off the balance sheet

Table 5. Response to either concept or standard

\begin{tabular}{|l|c|c|c|c|c|c|}
\hline & \multicolumn{2}{|c|}{ UK } & \multicolumn{2}{c|}{ US } & \multicolumn{2}{c|}{ Total } \\
\hline & Number & Percent & Number & Percent & Number & Percent \\
\hline Disagreeing & 17 & & 89 & & 106 & \\
\hline Agreeing & 21 & & 10 & & 31 & \\
\hline Total & 38 & 100 & 99 & 100 & 137 & 100 \\
\hline
\end{tabular}


Only $22.6 \%$ of respondents accepted the proposals in Exposure Draft 2 . For the standard setters this poses a challenge. After years of discussion, the issue of a Discussion Paper and two Exposure Drafts, only the minority of companies $(22.6 \%)$ agree with the proposals in ED 2. We would emphasise that we are only considering the opinions of the preparers of information and not the users.

The above table demonstrates, at least for companies, that the US respondents overwhelmingly reject either the concept or the proposed standard with $89.9 \%$ expressing disagreement compared to $44.7 \%$ for UK respondents. Of course, in the minds of the respondents, the concept and the standard may be inextricably linked. Assuming there is a distinction, it could be argued that if there is disagreement with the concept then it would be impossible for standard setters to make any progress.

However, if the concept is accepted but the proposed standard is rejected, it may be possible to produce a standard that is acceptable. In table 6 , we break down the 106 responses that disagreed with the ED proposals into the two categories of concept and standard. We accept that such an analysis requires an interpretative approach, but the respondents usually made it abundantly clear where their concerns lay.

In Table 6, separate the responses of the 106 companies disagreeing with either the concept or standard into those disagreeing with the concept and those accepting the concept but disagreeing with the standard. We acknowledge that our methodology has edged into an interpretive phase, but we consider the results reflect the opinions at the time and subsequent events

Table 6. Disagreement with concept/standard

\begin{tabular}{|l|c|c|c|c|c|c|}
\hline Category & \multicolumn{2}{|c|}{ UK } & \multicolumn{2}{c|}{ US } & \multicolumn{2}{c|}{ Total } \\
\hline $\begin{array}{l}\text { Disagrees with } \\
\text { concept }\end{array}$ & 5 & & No & $\%$ & No & $\%$ \\
\hline $\begin{array}{l}\text { Disagrees with } \\
\text { standard }\end{array}$ & 12 & & 63 & & 75 & \\
\hline Total & 17 & & 89 & & 106 & \\
\hline
\end{tabular}

The responses from the UK and the US are very close. Possibly, and more importantly such results may have given the standard setters some enthusiasm to continue to work on the standard. The fact that the two Boards finally set their own standards possibly reflects the results in Table 5.

This could give the standard setters some enthusiasm to continue to work on the standard as the majority of the respondents in this category have issues with the standard. 


\section{Conclusions}

The search for a new international standard for leases has proved a tortuous road. The analysis of the Comment Letters on the Discussion Paper and Exposure Drat 2 demonstrate a considerable resistance to the proposed changes, particularly by US companies.

Not noted in the above discussions is the concern expressed by some respondents on the apparent lack of agreement between the IASB and the FASB on some key issues. This was evident in CL 229 that discussed the measurement guidance and the apparent differences in the approaches of the two boards.

In general the boards favour different approaches to the measurement of the lease term. We believe that the new standard must reflect a consensus of opinion and respectfully request that the boards reconsider the use of the probability threshold approach.

It was considered that until these uncertainties were resolved the leasing project should not continue. Additionally, some respondents were of the opinion that the project should not continue until the requirements of lessors were also included.

The IASB has now issued IFRS 16 and presumably has judged that there was sufficient acceptance of change to introduce the standard. The FASB's new lease accounting standard, ASU 2016-02, Leases (Topic 842), was issued on February 25, 2016. There are differences in the standard, but one could suggest that the inability of the two Boards to devise a converged standard was one contributory factor to the demise of the convergence project.

\section{References}

Ashton RK (1985) Accounting for finance leases: a field test. Accounting and Business Research 15 (59): 233-238.

Beattie VA Goodacre, Thomson SJ (2006) International lease-accounting reform and economic consequences: The views of U.K. users and preparers. The International Journal of Accounting 41 (1): 75-103.

Bennett B, Bradbury M (2003) Capitalizing non-cancellable operating leases. Journal of International Financial Management and Accounting 14 (2): 101-114.

Breton G, Taffler R (1995) Creative accounting and investment analyst response. Accounting and Business Research 25 (98): 81-92.

Collins DL, Patel WR, Riley ME (2012) Financial reporting outcomes under rulesbased and principles-based accounting standards. Accounting Horizons 26(4): 681-705.

Durocher S (2008) Canadian Evidence on the Constructive Capitalization of Operating Leases. Accounting Perspectives 7(3): 227-256.

Frecka T (June 2008) Ethical Issues in Financial Reporting: Is International Structuring of Lease Contracts to Avoid Capitalization Unethical? Journal of Business Ethics 80(1): 45-59. 
Gopalakrishnan V, Parkash M (1996) The debt-equivalency of recognized vs. disclosed obligations: an examination of borrower and lender perceptions. Research in Accounting Regulation 10: 63-77.

Hooks J, van Staden CJ (2011) Evaluating Environmental Disclosures: The relationship between quality and extent measures. The British Accounting Review 43(3): 20013.

Imhoff E, Lipe R, Wright D (1991) Operating leases: Impact of constructive capitalization. Accounting Horizons 5 (1): 51-63.

Imhoff E, Lipe R, Wright D (1993) The effects of recognition versus disclosure on shareholder risk and executive compensation. Journal of Accounting, Auditing, and Finance 8 (4): 335-368.

McBarnet D, Whelan C (1991) The elusive spirit of the law: Formalism and the struggle for legal control. Modern Law Review 54(6): 848- 873.

McGregor W (1996) Accounting for leases: A new approach. Stamford Financial Accounting Standards Board. 
